\title{
NILAI-NILAI PENDIDIKAN ISLAM PADA PEMIKIRAN TASAWUF
}

\author{
Oleh: \\ Wahyu Mulyadin \\ Institut Agama Islam (IAI) Muhammadiyah Bima \\ wahyumuliadiniaimbima@gmail.com
}

\begin{abstract}
Abstrak:
Reformulasi metodologis untuk perkembangan tasawuf sangat berguna bagi masyarakat dari rentetan perkembanganya dari masa ke masa. Alternatifnya adalah tasawuf sosial sebagai ilmu yang pada dasarnya memiliki kerangka untuk amalan atau keshalihan pribadi namun dengan akhir yang tidak terbatas menjadi keshalihan sosial untuk membangun surga bagi diri sendiri dan umat manusia di dunia ini. Pada sisi lainnya, hakikat spiritual yang terkandung dalam pengamalan tasawuf Islam menekankan core values sufisme dalam diri seorang manusia seperti sikap muruah, waro'i, zuhud, qanaah, ikhlas, taqarub ilallah, moral. Secara esensial, tasawuf terletak pada pengejewantahan dari ajaran tentang ihsan, atau salah satu dari tiga serangkaia ajaran Islam, yaitu Islam sendiri, Iman, dan Ihasan. Esotorisme sufi adalah perwujudan dari sabda Nabi SAW bahwa ihsan adalah keadaan dimana ketika seorang manusia menyembah Allah SWT seolah-olah melihatnya. Sehingga pembelajaran atau paham kaum tasawuf, tidak lain adalah bagaimana menyembah Allah SWT.
\end{abstract}

Kata Kunci: Islam, Pendidikan, Nilai-Nilai Tasawuf.

\section{Pendahuluan}

Manusia yang dikaruniai akal, kemudian dengan akalnya manusia bisa berpikir untuk membedakan yang haq dan yang bathil, dan Rasulullah SAW, adalah salah-satu manusia terbaik diantara rasul Allah yang bisa mengembangkan pikirannya untuk kemaslahatan ummat. Dan teladan itulah yang di kembangkan oleh umatnya serta mengandalkan dalil-dalil agama. bahkan setelah beliau wafat, para umatnya tidak lagi merujuk langsung kepadanya, dengan pengertian tidak langsung bertanya dan konsultasi melainkan mengkaji langsung dari Al-Qura'n dan As-Sunnah yang di tinggalkan oleh beliau, sehingga banyak melahirkan perbedaan antara yang satu dengan lainnya. Dengan pembuktian bahwa perbedaan antara umat 
Islam tersebut, patut penulis menghadirkan tulisan yang berkaitan tentang pemikiran tasawuf, yag dimana pada umumnya umat Islam melakukan Taqorub Ilallah (mendekatan diri kepada Allah) dengan cara yang berbedabeda. Tapi semua itu tidak menjadi problem sepanjang berpegang teguh kepada Al-Qur,an dan As-Sunnah. Pada makalah ini, penulis menghadirkan pemikiran tasawuf sebagai bagian dari pemikiran Islam, yang kemudian besar kemungkinan akan menjadi contoh serta pelajaran bagi kaum muslimin.

Secara esensial, tasawuf terletak pada pengejewantahan dari ajaran tentang ihsan, atau salah satu dari tiga serangkaia ajaran Islam, yaitu Islam sendiri, Iman, dan Ihasan. Esotorisme sufi adalah perwujudan dari sabda Nabi SAW bahwa ihsan adalah keadaan dimana ketika seorang manusia menyembah Allah SWT seolah-olah melihatnya, dan kalaupun tidak melihatnya maka Allah SWT melihat makhluknya. Apa yang diajarkan atau paham kaum tasawuf, tidak lain adalah bagaimana menyembah Allah SWT dengan sutau kesadaran penuh agar senantiasa berada di dekatnya, dan Allah SWT selalu didekat dengan mahluknya seta dan selalu mengawasi setiap mahkluk cipataannya teramsuk manusia. Oleh karena itu, seorang manusia yang beriman diharuskan selalu mendekatkan diri menggapai ridhanya, yang mana pada hakikat penciptaan manusia tiada lain hanya untuk beribadah kepada Allah SWT. Berdasarkan pandangan uraian di atas, penulis berupaya mendeskripsikan pandangan teoritis yang berkaitan tentang nilai-nilai pendidikan pada pemikiran tasawuf. Gagasan ini masudkan untuk menjelaskan hakikat keberadaan tasawuf sebagai intrumen spiritual dalam mendidikandiri kepada Allah SWT. Pada bagian ahkir urauian artikel ini, diharapakn dapat memeberikan penguatan nilai-nilai keagaam dalam mengamalkan ajaran Islam.

\section{Pembahasan}

\section{Awal Mula Dan Perkembangan Tasawuf Dalam Islam}

Berkaitan dengan munculnya kata tasawuf juga tidak terlepas dari perbedaan pendapat para ulama bahkan ada yang berpendapat, pada masa Rasulullah SAW pun kata tasawuf sudah ada. Tetapi disisi lain, Al-Qusyairi mengatakan, "Tokoh-tokoh masyarakat muslim setelah Rasulullah SAW wafat tidak mempunyai panggilan (gelar) khusus selain, "Sahabat 
Rasulullah", karena tidak ada panggilan yang lebih utama daripada panggilan ini, mereka itu selanjutnya disebut "sahabat". Pada masa sesudah itu orang yang bersahabat dengan sahabat Rasulullah SAW, disebut "Tabi'in". mereka menganggap panggilan tersebut sebagai panggilan luhur. Orang yang hidup setelah masa tabi'in pun disebut sebagai "Tabi'it Tabi'in" (pengikut para tabi'in). kemudian jaman pun berganti dan derajat orang pun berbeda. Orang yang khusus dan menekun masalah agama kemudian disebut zahid (orang yang zuhud) dan abid (orang yang banayak ibadahnya). Selanjutnya muncullah bid'ah dan klaim-klaim suci dari setiap kelompok. Setiap kelompok mengklaim mempunyai orang zahid. Maka kelompok ahlussunnah yang senantiasa mendekatkan diri kepada Allah dan menjaga diri dari kelalaian mengkhususkan dirinya dengan sebutan sufi. Sebutan ini mulai dikenal di kalangan orang-orang besar tersebut sebelum abad ke-2 Hijriyah.

Berdasarkan uraian diatas, ada dua kecenderungan pendapat seputar munculnya kata tasawuf dan sufi: pertama, kata tasawuf dan sufi sudah dkenal sejak masa Nabi SAW dan Sahabat, kedua, kata tasawuf dan sufi baru dikenal sebelum abad kedua Hijriyah. Pendapat yang benar adalah bahwa tasawuf sebagai pengalaman zuhud sudah dikenal secara luas pada abad pertama dan menjelang berakhirnya abad kedua Hijriyah. Sedangkan kata tasawuf dan sufi baru muncul menjelang berakhirnya abad ke-2 Hijriyah, dan tersebar luas hingga menjadi salah satu cabang ilmu keislaman yang mempunyai kaidah-kaidah dan dasar-dasar seperti cabang ilmu lainnya.

\section{Tasawuf dalam Pengertian Etimologis (Bahasa)}

Para peneliti, baik klasik maupun kontemporer, berbeda pendapat seputar asal-muasal kata tasawuf. Perbedaan pendapat ini melahirkan banyak perbedaan, dan perbedaan mengimbas juga definisi tasawuf. Tetapi tanpa memaparkan perbedaan itu penulis langsung menguraikan yang menjadi kesepakatan para ulama tentang pengertian tasawuf menurut bahasa. Yaitu kata tasawuf, adalah masdar dari kata sufi yang berasal dari bahasa Arab shuuf (bulu domba), yaitu orang memakai baju dari bulu domba, sebagaimana taqammush diartikan memakai qamish (gamis). 
Peneliti kontemporer pun memilih pendapat ini. ${ }^{1}$ Selain itu, jika dibandingkan dengan pendapat lain, pendapat ini merupakan pendapat yang paling tua usianya, karena sebagian masyarakat melakukan hidup zuhud dan merasa cukup dengan hanya memakai baju dari bulu domba kasar. Pendapat ini diperkuat dengan atsar yang diriwayatkan dari Ibnu Abas. Ia berkata; "Tujuh puluh Nabi menempuh perjalanan dalam keadaan berhaji dan mengenakan pakian dari bulu domba." (HR .Al-Hakim dalam AlMustadrak).

\section{Tasawuf dalam Pengertian Terminologis (Istilah)}

Pengertian tasawuf secara terminlogis, juga tidak terlepas dari beragamnya kecenderungan seorang sufi mengedepankan pendapat, maka disini juga yang menjadi kesimpulan, tasawuf secara istilah yaitu berati shafaa' (jernih) dan mushaadah (menyaksikan). Dengan demikian tasawuf berarti "menjernihkan hati dan mengikhlaskan/memurnikan ibadah semata hanya untuk Allah." Jika seorang hamba telah ikhlas demi Allah, mengikuti perintahnya, menjauhi larangannya, serta telah menjernihkan hatinya, maka ia telah mendapatkan kedudukan musyaahadah ${ }^{2}$. Definisi ini telah dipilih dan dikuatkan oleh Dr. Abdul Hamid Mahmud. Dia mengatakan, "dengan menjumpai definisi dua sisi tersebut, maka telah menjumpai dua sisi yang menurut kita adalah suatu kesatuan yang sempurna. Dua sisi itu adalah wasilah (sarana,alat) dan ghayah (tujuan, sasaran). Yang di sebut wasilah dalam dunia taswuf adalah shafaa' (kejernihan hati), sedangkan ghayah-nya adalah musyahadah. Dengan merujuk definisi ini, maka tasawuf adalah jalan (tharik) dan tujuan (ghayah)."

\section{Fase-Fase Perkembangan Tasawuf Dalam Islam}

\section{Fase Pertama: Fase Zuhud}

Fase perkembangan tasawuf berlangsung pada abad I dan II Hijriyah. Pada dua abad ini muncul benih-benih tasawuf pertama. Benih pertama dalam bentuk kecenderungan kuat terhadap perilaku zuhud yang menguasai dunia ketika itu. Al-Qur'an mendorong umat Islam untuk

\footnotetext{
${ }^{1}$ Abdul Fattah Syayid Ahmad, Tasawuf antara Al-Ghajali dan Ibnu Taimiyah (Jakarta : Khalifa, 2005), 11.

${ }^{2}$ Abdul Fattah Syayid Ahmad, Tasawuf antara Al-Ghajali dan Ibnu Taimiyah...,13
} 
bersikap zuhud dalam melihat dunia (tetapi bukan membencinya), membekali diri dengan taqwa, ibadah, shalat malam, dan wara'. Semua amal ini menyebabkan kita mendapat ridha Illahi dan mengantarkan kita ke surga. Datanglah kemudian hadis Rasulullah SAW yang memotifasi manusia untuk zuhud. Bahkan Rasulullah SAW sendiri menjadikan diri beliau sebagai teladan nyata dalam praktek zuhud dan menjauhi gemerlapan dunia. Rasulullah SAW dan para sahabatnya adalah manusia yang menempuh hidup zuhud disaat kondisi memungkinkan untuk hidup mewah. beliau bekerja di dunia hanya untuk sekedar mendapat makan. Selain sikap zuhud yang didorong dan di motifasi oleh doktrin-doktrin agama, sikap zuhud juga bekembang karena perbedaan antara Ali dengan Muawiyah yang menyebabpakan perselisihan antara kedua golongan tersebut. Semua perbedaan itu memecah belah umat Islam dalam kelompok dan faksi. Setiap faksi mendukung kelompok tertentu dengan dalil-dalil dan nash-nash agama. Sehingga pada sebagian kelompok memilih tidak terlibat dalam pertikaian politik ini, dan meninggalkan hiruk-pikuk perbedaan untuk beribadah kepada Allah. Mereka berkonsentrasi untuk mempelajari AlQur'an dan As-Sunnah, meninggalkan kenikmatan dunia serta meletakkan cita-cita luhur mereka pada kehidupan akhirat. Disini gerakan zuhud mulai muncul dan kuat. ${ }^{3}$

\section{Fase Kedua: Tasawuf di Abad Ketiga dan Empat}

Pada abad ketiga Hijriyah, mulai ada perkembangan penting pada praktek zuhud. Zuhud pada abad ini tidak lagi menjadi sebuah situs pribadi, tetapi menjadi sebuah gerakan rapi dimana para pesertanya disebut sebagai "sufi". Para sufi ini mulai membicarakan tema yang baru pada masa itu. Tema-tema yang dibicarakan antara lain adalah kondisi jiwa. Dan bisa dikatakan bahwa tasawuf pada abad III dan IV Hijriyah mempunyai dua orientasi: pertama; orientasi suni, para pengikut orientasi ini mengikat diri pada aturan Al-Qur'an dan As-Sunah. Kedua; orientasi falsafi, pengikut orientasi ini cenderung pada orientasi syathahat, berangkat dari kondisi fana' sampai mengampanyekan teori itihad dan hulu. Pada abad V Hijriyah, orientasi sunni berjalan dengan baik, sementara orientasi falsafi tidak Nampak perkembangannya, meski pada abad VI $H$ dan abad-abad

${ }^{3}$ Abdul Fattah Syayid Ahmad, Tasawuf antara Al-Ghajali dan Ibnu Taimiyah..., 
selanjutnya muncul kembali dengan bentuknya yang lain ditangan para filsof sufi.

\section{Fase Ketiga: Tasawuf di Abad VI dan VII Hijriyah}

Pada fase ini, tasawuf falsafi muncul lagi dengan jelas dan berkembang pesat. Tasawuf falsafi diwarnai oleh banyak sekali unsur-unsur dari luar islam, baik Yunani, Persia, India dan Kristen. Kenyataan ini dengan adanya kata dan istilah filsafat yang berkaitan dengan filsafat asing tersebut. Istilah dan kosakata filsafat asing tersebut tertuang dalam bukubuku karya para sufi falsafi. ${ }^{4}$

\section{Tipologi Tasawuf Dalam Islam (Falsafi, Akhlaqi, Amali, Haraqi, dan Tarekat)}

Munculnya konsep tipologi tasawuf antara lain tasawuf akhlaki, amali, falsafi, dan tarekat. Sesungguhnya tipologi tasawuf memiliki tujuan yang sama yaitu melalui mendekatkan diri kepada Allah SWT. Dengan cara membersihkan diri dan menjauhkan diri dari perbuatan tercela, serta manghasilkan perbuatan terpuji. Dan adanya anggapan bahwa konsep tasawuf erat kaitannya dengan mistis dengan Tuhan, dalam pengertian seorang sufi merasakan dapat berhubungan langsung dengan Tuhan.

\section{Tasawuf Falsafi}

Tasawuf Falsafi adalah sebuah konsep ajaran tasawuf yang mengenal Tuhan (ma'rifat) dengan pendekatan rasio (filsafat) hingga menuju ketingkat yang lebih tinggi, bukan hanya mengenal Tuhan saja (ma'rifatullah) melainkan yang lebih tinggi dari itu yaitu wihdatul wujud (kesatuan wujud). Bisa juga dikatakan tasawuf falsafi yakni tasawuf yang kaya dengan pemikiran-pemikiran filsafat. Di dalam tasawuf falsafi metode pendekatannya sangat berbeda dengan tasawuf yang lain. Tasawuf falsafi dalam dunia Islam, Tasawuf falasafi secara sederhana dapat didefenisikan sebagai kajian dan jalan esoteris dalam Islam untuk mengembangkan kesucian bathin yang kaya dengan pandangan-pandangan filosofis. Keberadaan tasawuf bercorak falsafi ini pada satu sisi telah menarik perhatian para ulama yang pada awalnya kurang senang dengan kehadiran filsafat dalam khazanah Islam. Sementara bagi para ulama yang menyenangi

Taimiyah...,41

4 Abdul Fattah Syayid Ahmad, Tasawuf antara Al-Ghajali dan Ibnu 
kajian-kajian filsafat dan sekaligus menguasainya, tasawuf falsafi bagaikan sungai yang airnya demikian bening dan begitu menggoda untuk direnangi. Ulama pertama yang dapat dianggap sebagai tokoh tasawuf falsafi adalah Ibn Masarrah (w. 319/931) yang muncul dari Andalusia. Sekaligus dia dapat dianggap sebagai filosof sufi pertama dalam dunia Islam. Pandangan filsafatnya adalah emanasi yang mirip dengan emanasi plotinus. Menurutnya, melalui jalan tasawuf manusia dapat melepaskan jiwanya dari belenggu/penjara badan dan memperoleh karunia Tuhan berupa penyinaran hati dengan nur Tuhan. Suatu ma'rifah yang memberikan kebahagiaan sejati. Ia juga menganut pandangan bahwa kehidupan di akhirat bersifat ruhani, sehingga di akhirat kelak manusia dibangkitkan ruhnya saja, tidak dengan badan.

\section{Tasawuf Akhlaqi}

Tasawuf akhlaki lebih lanjut kita ikuti uraian yang di berikan Harun Nasution menurutnya ketika mempelajari tasawuf ternyata Al-Qur'an dan Hadits mementingkan Akhlak. Al-Qur'an dan Hadits menekankan nilai-nilai kejujuran, kesetikawanan, persaudaraan, rasa kesosialan, keadilan, tolongmenolong, murah hati, suka memberi maaf, baik sangka, berkata benar, pemurah, keramahan, bersi hati, berani, kesucian, hemat, menepati janji, disiplin, mecintai ilmu dan berpikir lurus. Selanjutnya pada tasawuf akhlaki pendekatan yang di gunakan adalah pendekatan yang serupa, yaitu pendekatan akhlak yang tahapan terdiri dari takhalli (mengosongkan diri dari akhlak yang buruk), tahalli (menghiasinya dengan akhlak yang terpuji), dan tajalli (terbukanya dinding penghalang (hijab)) yang membantasi manusia dengan Tuhan, sehingga nur Ilahi tampak jelas padanya. ${ }^{5}$

\section{Tasawuf Amali}

Berbeda dengan ilmu yang lain, makrifat pada hakikatnya tidak bisa dicapai tanpa amal, dalam artian perbuatan-perbuatan yang mencapai tingkat-tingkat spiritual, seperti pembersihan jiwa (tazkiyat al-nafs), latihanlatihan spiritual serta praktik-praktik dari keutama-keutamaan moral, atau akhlak yang mulia. Maka tasawuf dalam beramal bukan untuk orang yang suka merenung dan latihan-latihan spiritual, tetapi untuk mereka yang telah melaksanakan pengetahuan teoritis mereka dalam kehidupan sehari-hari.

\footnotetext{
${ }^{5}$ Abududdin Nata, Akhlak Tasawuf...,18
} 
Tanpa amal dan praktik spiritual pada level keseharian, tasawuf tidak akan menampakkan kebesaran, pengaruh, dan efektivitasnya. ${ }^{6}$

\section{Tarekat}

Tarekat adalah dipahami sebagai jalan spiritual yang ditempuh seorang sufi dan kata tarekat juga dipakai untuk merujuk sebuah kelompok persaudaraan atau ordo spiritual yang biasanya didirikan oleh seorang sufi besar seperti Abdul Kadir Jailani, Sadzili, Jalal Al-Din Rumi, dan lainlainnya. Tarekat kaitan dalam zikir biasanya dipahami senagai melafalkan ungkapan tertentu. Yang populer dalam kalimat tersebut adalan ucapan La ilaha illa Allah, yang artinya tiada Tuhan selain Allah, dan tentunya ini disandarkan pada hadits Nabi SAW yang bersabda seutama-utamanya zikir adalah La ilaha illa Allah. Tetapi ketika zikir telah mencapai tingkat intnsitas tertentu, maka para pengamal zikir biasanya hanya menyebut "Allah". Bahkan dalam tarekat tertentu, kita hanya menyebut "Hu" barang kali berasal dari kata "Huwa" dengan mewakafkan huruf terakirnya. ${ }^{7}$

\section{Core Values Sufisme: Muruah, Waro'i, Zuhud, Qanaah, Ikhlas, Taqarub} Ilallah, Moral.

Nilai yang terkandung dalam pengamalan kaum sufi memiliki realitasnya sendiri dan menimbulkan cirri lain dalam keberagamannya, Hal tersebt akan di uraikan pada poin sebagai berikut:

\section{Waro'}

Waro' yaitu meninggalkan hal-hal yang bersifat subhat (sesuatu yang belum jelas kehalalanya). Sifat waro' dalam tasawuf dapat dibagi empat; pertama, waro' Al-Adl yaitu meninggalkan segala barang yang haram menurut fatwa fuqho' (ahli fiqh), seperti makan barang riba, muamalah yang fasidah (rusak). Kedua, waro' As-sholihin, yaitu meninggalkan barang-barang yang subhat. Ketiga, waro' Al-Muttaqin, yaitu meninggalkan suatu yang tidak ada bahayanya (halal) karena takut dengan sesuatu yang bahaya (haram). Keempat, waro' Ash-shidiqin, yaitu

\footnotetext{
${ }^{6}$ Mulyadhi kartanegara, Menyelami Lubuk tasawuf...,170.

${ }^{7}$ Mulyadhi kartanegara, Menyelami Lubuk tasawuf..., 253.
} 
meninggalkan dari afat (hanya karena takut terlena atau takut lupa dari Allah) ${ }^{8}$

\section{Zuhud}

Secara etimologis, zuhud berarti raghaba 'ansyai'in wa tarakahu, artinya tidak tertarik terhadap sesuatu dan meninggalkannya. Zahada fi aldunya, berarti mengosongkan diri dari kesenangan dunia untuk ibadah. Berbicara tentang arti zuhud secara terminologis menurut (Prof. Dr. Amin Syukur), tidak bisa dilepaskan dari dua hal. Pertama, zuhud sebagai bagian yang tak terpisahkan dari tasawuf. Kedua, zuhud_sebagai moral (akhlak) Islam dan gerakan protes. Apabila tasawuf diartikan adanya kesadaran dan komunikasi langsung antara manusia dengan Tuhan sebagai perwujudan ihsan, maka zuhud merupakan suatu station (maqam) menuju tercapainya "perjumpaan" atau ma'rifat kepada-Nya.

Zuhud disini berarti tidak merasa bangga atas kemewahan dunia yang telah ada ditangan, dan tidak merasa bersedih karena hilangnya kemewahan itu dari tangannya. Bagi Abu Wafa al-Taftazani, zuhud itu bukanlah kependetaan atau terputusnya kehidupan duniawi, akan tetapi merupakan hikmah pemahaman yang membuat seseorang memiliki pandangan khusus terhadap kehidupan duniawi itu. Mereka tetap bekerja dan berusaha, akan tetapi kehidupan duniawi itu tidak menguasai kecenderungan kalbunya dan tidak membuat mereka mengingkari Tuhannya. Lebih lanjut at-Taftazani menjelaskan bahwa zuhud adalah tidak bersyaratkan kemiskinan. Bahkan terkadang seorang itu kaya, tapi disaat yang sama diapun zahid. Ustman bin Affan dan Abdurrahman ibn Auf adalah para hartawan, tapi keduanya adalah para zahid dengan harta yang mereka miliki. ${ }^{9}$

\section{Taqorub Ilallah}

Dalam aspek hubudiyah (posisis kita sebagai hamba), taqarub Ilallah (mendekatkan diri kepada Allah) adalah sebagai aspek utama para sufi dan ahli tarekat, biasanya di upayakan dengan beberapa cara yang cukup mistis. Diantara cara yang biasa dilakukan oleh para pengikut tarekat atau sufi

\footnotetext{
${ }^{8}$ Moch. Djamaludin Achmad. Jalan menuju Allah...,2

${ }^{9}$ Syukur dan Abdul Muhayya, Tasawuf dan Krisis..., 45
} 
untuk mendekatkan diri kepada Allah dengan lebih efektif dan efisien: tawasul, muraqabah, dan khalwat.

a) Tawasul (berwasilah) dalam upaya mendekatkan diri kepadaAllah yang biasa di lakukan dalam tarekat suatu cara atau wasilah agar pendekatan diri kepada Allah dapat di lakukan dengan ringan dan lebih mudah.

b) Muraqabah (kontemplasi) yaitu duduk bertafakur atau mengheningkan cipta dengan penuh kesungguhan hati, dengan seolah-olah berhadapan dengan Allah, meyakini diri bahwa Allah senantiasa mengawasi dan memperhatikannya.

c) Khalwat atau 'uzlah yaitu mengasingkan diri dari hiruk-pikuk nya urusan duniawi, sebagaiana ada yang mengajari secara fisik dan sebagian yang lain tidak mengajari secara fisik.

\section{Moral}

Moral yang dimiliki oleh penganut tarekat atau sufi, adalah tidak akan pernah menyimpang dan selalu mengandung nilai-nilai yang benar atas dasar kesadaran, bujukan atas dasar kekuatan apapun dan juga bukan karena paksaan. Tetapi berdasarkan moral yang timbul dari hati yang bersangkutan.

\section{Tokoh-Tokoh Tasawuf Dan Pemikirannya}

Pada poin ini tentu tidak semua tokoh-tokoh taswuf yang anda ketahui untuk penulis paparkan, tetapi semua itu dibatasi, dengan batasan pembahasan yang kemudian penulis lontarkan. Adapun tokoh-tokoh tasawuf yang penulis kemukakan adalah:

\section{Ibn Athaillah As-Sakandary}

Nama lengkapnya Ahmad ibn Muhammad Ibn Athaillah as Sakandary (w. 1350M), dikenal seorang Sufi sekaligus muhadits yang menjadi faqih dalam madzhab Maliki serta tokoh ketiga dalam tarikat al Syadzili. Penguasaannya akan hadits dan fiqih membuat ajaran-ajaran tasawufnya memiliki landasan nas dan akar syariat yang kuat. Karyakaryanya amat menyentuh dan diminati semua kalangan, diantaranya Al Hikam, kitab ini ditujukan untuk meningkatkan kesadaran spiritual di kalangan murid-murid tasawuf. Kitab lainnya, Miftah Falah Wa Wishbah Al Arwah (Kunci Kemenangan dan Cahaya Spiritual), isinya mengenai dzikir, 
Kitab al Tanwir Fi Ishqat al Tadhbir (Cahaya Pencerahan dan Petunjuk Diri Sendiri), yang disebut terakhir berisi tentang metode madzhab Syadzili dalam menerapkan nilai Sufi, dan ada lagi kitab tentang guru-guru pertama tarekat Syadziliyah - Kitab Lathaif Fi Manaqib Abil Abbas al Mursi wa Syaikhibi Abil Hasan. ${ }^{10}$

\section{Abdul Qadir Al-Jilani}

Abdul Qadir Al Jilani dilahirkan pada tahun 471 H/1078 M. di Jailan Tabaristan dan meninggal di Baghdad Irak..ia adalah seorang Sufi yang sangat tekenal dalam agama Islam. Ia adalah pendiri tharikat Qadiriyyah. Abdul Qadir mulai menggunakan dakwah Islam setelah berusia 50 tahun. Dia mendirikan sebuah tharikat dengan namanya sendiri. Syeikh Abdul Qadir disebut-sebut sebagai Quthb (poros spiritual) pada zamannya, dan bahkan disebut sebagai Ghauts Al Azham (pemberi pertolongan terbesar), sebutan tersebut tidak bisa diragukan karena janjinya untuk memperkenalkan prinsip-prinsip spiritual yang penuh keghaiban. Buku karangannya yang paling populer adalah Futuh Al Ghayb (menyingkap kegaiban). Melalui Abdul Qadir tumbuh gerakan sufi melalui bimbingan guru tharikat (mursyid). Jadi Qadiriyah adalah tharikat yang paling pertama berdiri.

\section{Al Hallaj}

Nama lengkapnya Abul Muggist al-Husain bin Mansyur Al Hallaj, dilahirkan di Persia tahun 244 H/858 M. seorang Sufi di Thus yang dituduh Musyrik oleh khalifah dan oleh para pakar Abbasiyah di Baghdad oleh karenanya dia dihukum mati. Al Hallaj pertama kali menjadi murid Tharikat Syeikh Sahl di Al Tutsari, kemudian berganti guru pada Syeikh Al Makki, kemudian mencoba bergabung menjadi murid Al Junaed Al Baghdadi, tetapi ditolak.

Al Hallaj terkenal karena ucapan ekstasisnya "Ana Al Haqq" artinya Akulah Yang Maha Mutlak, Akulah Yang Maha Nyata,bisa juga berarti "Akulah Tuhan", mengomentari masalah ini Al Junaid menjelaskan "melalui yang Haq engkau terwujud", ungkapan tersebut mengandung makna sebagai penghapusan antara manusia dengan Tuhan. Menurut Junaid " Al Abd yahqa al Abd al Rabb Yahqa al Rabb" artinya pada ujung perjalanan

${ }^{10}$ Laily Mansyur. Ajaran dan teladan para sufi..,218. 
"manusia tetap sebagai manusia dan Tuhan tetap menjadi Tuhan". Pada jamannya Al Hallaj dianggap musrik, berdasarkan laporan-laporan masyarakat, maka pemerintah segera menahannya dan menyeretnya di pengadilan dan ia pun berakhir dengan hukuman mati. Selama dipengadilan al-Khallaj banyak menulis hingga 48 buah buku. Judul-judul bukunya banyak yang asing dan isinya juga banyak yang aneh dan sulit dipahami.

\section{Jalaludin al-Rumi}

Nama lengkapnya ialah Muhammad bin Muhammad bin Husein alkhtbi al-Bakri, dikenal dengan Jalaludin al-Rumi. Ia dilahirkan di balkh Persia pada tahun 604 H/1217 M. Jalaludin al-Rumi dilahirkan dari keuarga yang taat beragama. Ayahnya seorang sufi yang terlibat dalam kegiatan kerohanian di daerahnya. Ia mendapatkan pendidikan di Anatolia, kemudia mengembara ke beberapa negeri dalam rangka menuntut ilmu. Ia bertemu dengan Fariduddin Attar yang kemudian berkomentar bahwa Jalaludi alRumi menyalakanapi cinta ketuhanan yang mengimbau dunia. Jalaludi alRumi meninggalkan karya-karya tulis amat banyak, amat berharga dan dipelajari sepanjang masa.

Karya besar al-Rumi adalah Al-Matsnawi yang berisi lebih dari 26.000 baris syair, terdiri dari 6 jilid mengandung ajaran tasawuf yang diperuntukkan bagi mereka yang memasuki lautan tasawuf dan tenggelam didalamnya. Al-Rumi sediri menyatakan bahwa matsnawi adalah kumpulan masalah-masalah agama yang besar dan pokok, dan dapat disebut dengan Al-fiqhu al-Akbar, karena ajarannya mengandung tentang keesaan Tuhan, ketaataan pada agama, pembersihan jiwa, pemantapan hati dan pikiran kepada Allah SWT. Dalam al-Matsnawi, ajaran-ajaran al-Rumi dikususkan bagi orang-orang sufi dan tidak untuk kaum muslimin. ${ }^{11}$ ]

\section{Al-Naqsabandi}

Nama lengkapnya ialah Baharuddin Muhammad al-Bukhari alNaqsabandi dilahirkan didaerah Hinduan, Bukhara, pada tahun 717 H/1317 M. Ia digelar dengan al-Naqsabandi karena mampu menempa dan mengukir berbagai sifat keutamaan dan kebaikan dalam hati setiap orang. AlNaqsabandi belajar ilmu dasar di daerahnya Bukhara, dan kemudian

\footnotetext{
${ }^{11}$ Laily Mansyur. Ajaran dan teladan para sufi.., 209.
} 
melanjutkan kajian ilmunya kepada ulama-ulama besar di luar daerah dengan masa yang cukup panjang. setelah kemudian lantas ia kembali ke daerah kelahirannya Hinduan dan membuka pesantren dan membangun ribath untuk tarekatnya. Di sini pula ia meninggal dunia dengan tenang pada tahun $791 \mathrm{H} / 3189 \mathrm{M}$ dalam usia 74 tahun. $^{12}$

\section{Sufisme Dan Gerakan Tarekat Di Indonesia}

\section{Sufisme}

Pada esensinya seperti yang sudah di uraikan dihalaman depan bahwa kata tasawuf adalah masdar dari kata sufi, dalam pengertian ketika kita berbicara tasawuf maka itu adalah sufi. Dalam banyak uraian diatas bahwa tasawuf adalah kesadaran adanya komunikasi dan dialog langsung antara seorang muslim dengan sang khalik. Tasawuf juga merupakan suatu sistem latihan dengan penuh kesungguhan untuk membersihkan , mempertinggi dan memperdalam kerohanian dalam rangka mendekatkan diri kepada Allah. Sufisme adalah gerakan menawan banyak wilayah dunia Islam dalam menentukan kelanjutan dari ajara Islam, dalam metodologinya, yaitu menggabungkan sebanyak mungkin warisan kaum sufi yang dapat direkonsiliasikan dengan Islam ortodoks, supaya dapat memberikan sumabangan positif kepadanya. Motif moral sufisme di tekankan dan sebagian dari tekhnik zikir dan muraqabah, Konsentrasi rohaniyah di ambil pula.

\section{Gerakan Tarekat di Indonesia}

Tarekat berarti jalan, tarekat (jalan) yang di pahami adalah jalan spiritual yang di tempuh sufi, juga dipakai untuk merujuk sebuah kelompok pesudaraan atau ordo spiritual yang biasanya didirikan oleh seorang sufi. Nama tarekat dinisbatkan kepada nama-nama pendirinya atau julukan yang diberikan oleh para pengikutnya. Tarekat sufi atau kelompok-kelompok sufi berkembang diseluruh pelosok daerah muslim di Indonesia, dengan perkembangan dan gerakan yang sudah terbukti, dengan pembuktian adanya berbagai macam nama tarekat yang ada di Indonesia. Namun, dalam perjalanan waktu, ajaran dan teladan pribadi kaum sufi yang menjalani kehidupan menurut aturan-aturan yang telah ditetapkan agama mulai banyak menarik kelompokmanusia. Di antara abad kesembilan dan kesebelas, mulai

\footnotetext{
${ }^{12}$ Laily Mansyur, Ajaran dan teladan para sufi..., 224
} 
muncul berbagai tarekat sufi, yang meliputi para ahli dari segala lapisan masyarakat. Ketika tarekat sufi, atau persaudaraan sufi ini muncul, pusat kegiatan sufi bukan lagi di rumah-rumah pribadi. Yang berikut ini hanya contoh dari beberapa tarekat sufi yang secara pribadi dengan pengetahuan penulis yang menyebar di indonesia.

a. Tarekat Qadiriyah. Tarekat ini didirikan oleh Syekh 'Abdul Qadir alJailani (1166 M) dari Gilan di Iran, yang kemudian bermukim di Baghdad, Irak. Setelah wafatnya, tarekatnya disebarkan oleh putraputranya. Tarekat Qadiriyah telah menyebar ke banyak tempat, termasuk Suriah, Turki, beberapa bagian Afrika seperti Kamerun, Kongo, Mauritania dan Tanzania, dan di wilayah Kaukasus, dan Ferghana di Asia Tengah, serta di tempat- tempat lain seperti Indonesia.

b. Tarekat Maulawiyah. Tarekat ini berpusat di sekitar Maulana Jalaluddin Rumi dari Qonya di Turki (1273 M). Sekarang kebanyakan terdapat di Anatolia di Turki, Indonesia dan pada akhir-akhir ini di Amerika Utara. Para pengikut tarekat ini juga dikenal sebagai para darwis yang berputar-putar.

c. Tarekat Naqsyabandiyah. Tarekat ini mengambil nama dari Syekh Baha'uddin Naqsyaband dari Bukhara (1390 M). Tarekat ini tersebar luas di wilayah Asia Tengah, Volga dan Kaukasus, Cina bagian baratlaut dan baratdaya, Indonesia, di anak-benua India, Turki, Eropa dan Amerika Utara. Ini adalah satu-satunya tarekat terkenal yang silsilah penyampaian ilmunya kembali melalui penguasa Muslim pertama, Abu Bakar, tidak seperti tarekat-tarekat sufi terkenal lainnya yang asalnya kembali kepada salah satu imam Syi'ah, dan dengan demikian melalui Imam 'Ali, sampai Nabi Muhammad SAW.

\section{Gerakan Neo Sufisme (Sufi Berdasi/Sufi Corporate).}

Ketika dalam bukunya Hamka, Tasawuf Modern, beliau bersungguh-sungguh telah meletakkan dasar-dasar bagi neo sufisme ditanah air kita. Di dalam buku itu terdapat alur pikiran yang meberi apresiasi yang wajar kepada esotoris Islam. Muculnya neo-sufisme adalah untuk menklaim dan pembaharu, terhadap klaim sufisme yang dianggap melenceng dari esotoris ajaran Islam. Pergerakan neo-sufisme juga tetap meneruskan tentang praktek ajaran sufisme asalkan sesuai dengan syariah. Bahkan tidak terdapat bukti yang kuat dari garis Hambali semacam Ibnu Taymiyah atau, 
Ibnu Al-Qoyyim Jauziyah menentang bentuk sufisme.Dalam konteks keIndonesiaan, banyak orang yang di sibukan oleh dunia, tetapi prinsip keIslaman tidak di pinggirkan, dengan pengertian Al-Qur'qn dan As-Sunnah tetap di kedepankan. contoh; orang kantor dan pelaku bisnis yang menerepakan prinsip-prinsip kesufian dalam praktek bisnis mereka. Pemandangan para sufi berdasi yang mengerjakan sholat dhuha di tengahtengah kesibukannya, menghadiri pengajian di sela-sela jam kantor, atau hadir dalam halaqoh-halaqoh zikir selepas jam kantor sudah bukan sesuatu yang asing terlihat di kota-kota besar di negeri ini. Munculnya para trainer dan motivator muda yang megacu kepada kesuksesan Ary Ginanjar yang berhasil mendorong pebisnis negeri ini merupakan indikasi bertumbuh kembangnya komunitas sufi berdasi ini. Inilah gairah ibadah yang dirindukan para sufi. Gairah yang merngkum segenap realitas sebgai suatu manifestasi Ilahi dan kerinduan untuk membakar diri dalam api cintanya kepada sang kholik.

\section{Penutup}

Upaya pengembangan kualitas keberagamaan untuk menghayati Tuhan dalam Islam sudah diamalkan di masa Rasul Allah, meskipun term khusus sebagai konseptualisasi gejala ini baru timbul dalam sejarah di kemudian hari. Reformulasi metodologis untuk perkembangan tasawuf sangat berguna bagi masyarakat dari rentetan perkembanganya dari masa ke masa. Alternatifnya adalah tasawuf sosial sebagai ilmu yang pada dasarnya memiliki kerangka untuk amalan atau keshalihan pribadi namun dengan akhir yang tidak terbatas menjadi keshalihan sosial untuk membangun surga bagi diri sendiri dan umat manusia di dunia ini. Terlepas dari adanya pebedaan dan kritikan pedis dari masyarakat, perkembangan ajaran tasawuf tidak pernah lumpuh. Sebagai suatu fenomena dalam kenyataan sejarah, pola hidup zuhud di mungkinkan oleh berbagi faktor. Faktor-faktor yang terkemuka dalam perkembangan dan kebangkitan spiritual ajaran tasawuf tidak terlepas dari ajaran Al-Qur'an dan As-Sunnah. Walaupun di kemudian hari ada pandangan dan persepsi yang tidak bernilai positif terhadap ajaran ilmu tasawuf bahkan di anggap sesat, serta tokoh tasawuf (sufi) terkenal (Al-Khallaj) pada akhirnya di hukum mati. Dengan sekian abad, mulai dari awal perkemkebangannya hingga di abad kontemporer, tasawuf masih akrab 
dengan kaum muslimin, yang ingin bertaqarub Ilallah dengan cara dan ajaran tasawuf tersebut, tetapi di mana ada kebaikan pasti di susul oleh kebathilan dengan pengertian perjalanan dan perkembangan ilmu tasawuf tetap melewati tantangan, begitupun sebenarnya dakwah yang di lakukan oleh ajaran-ajaran jamaah yang lain. Tapi bagi para mubaligh jadikanlah tantangan itu sebagai nikmat, bukan justru sebaliknya atau di jadikan sebagai problem.

\section{DAFTAR PUSTAKA}

Ahmad, Abdul Fattah Syayid. Tasawuf antara Al-Ghajali dan Ibnu Taimiyah. Cet. 1; Jakarta : Khalifa 2005.

AS, Asmaran. Pengantar Studi Tasawuf. Cet .2 Jakarta: PT Rajagrafindo Persada. 1996.

Nata, Abududdin. Akhlak Tasawuf.

Simuh. Tasawuf dan perkembangan dalam Islam. Cet.2 Jakarta: PT Rajagrafindo Persada.1997.

Kartanegara, Mulyadhi. Menyelami Lubuk tasawuf. Penerbit Erlangga. Jln. H. Baping Raya. No.100. Ciracas Jakarta 13740.

Achmad, Moch. Djamaludin. Jalan menuju Allah.

Mansyur, Laily. Ajaran dan teladan para sufi. Ed.1. Cet. 2. Jakarta: PT. Rajagrafindo Persada.1999.

Syukur dan Muhayya, Abdul. Tasawuf dan Krisis. Yogyakarta: Pustaka Pelajar. 